\title{
Reconstruction with using a comprehensive assessment
}

\author{
$M V$ Perkova ${ }^{*}$, I $N$ Chechel, A M Dubino, and I P Chechel \\ Belgorod State Technological University named after V.G. Shukhov, 308012, Belgorod, Russia
}

\begin{abstract}
The relevance of the topic is determined by the need to solve a complex of problems related to the reconstruction of cultural heritage objects of regional significance with adaptation to modern use, taking into account investment attractiveness. The problem of preserving cultural heritage in a post-industrial society is due to the preservation of the memory of the place, its history and traditions. Preservation and restoration with the cultural heritage objects adaptation to a new function preserves the urban identity, makes the urban environment unique and attractive for residents.Urban planning and space-planning analysis of the cultural heritage object was carried out with the aim of its reconstruction and adaptation for modern use. Options for reconstruction and adaptation were developed. The decision options are justified by a comprehensive assessment for decision-making. The list of criteria and questions for quantitative assessment were clarified specifically for the process of reconstruction of the cultural heritage site.As a result of the quantitative analysis, an objective result was obtained that allows evaluating the effectiveness of the developed proposals from the point of view of the population, authorities, business and other participants in urban development. The optimal conceptual project proposal was identified. The proposed measures will help to preserve the object of cultural heritage, create new jobs, and implement cultural and social projects for various consumer groups.
\end{abstract}

\section{Introduction}

The relevance of the topic is determined by the need to solve a set of problems related to the reconstruction of cultural heritage objects of regional significance with adaptation to modern use, taking into account investment attractiveness (n73-fz. 2020).

The problem of preserving cultural heritage in a post-industrial society is due to the preservation of the memory of the place, its history and traditions for the comprehensive development of human potential [15]. Domestic and foreign experience shows that reconstruction with adaptation to modern functions contributes to the formation of the identity of settlements, the opening of new jobs, socialization and attraction of tourist flows, as well as improving the ecological state of the urban environment $[4,6]$. M.S. Stieglitz, R.P. Podolsky, I.V. Fedoseeva, Yu.I. Kazantsev, S.P. Kalita, I.N. Yurkin,

\footnotetext{
* Corresponding author: perkova.margo@mail.ru
} 
M.A. Granstrem, S.V. Sementsov, A.A. Skokan, T.A. Slavina, V I.Sheredega, et al. were engaged in the issues of history, preservation, and protection of cultural heritage in Russia and the CIS countries. The research of A.E. Enin, L.I. Kolesnikova, V. Sobrovin, V.V. Ovchinnikov, M.V. Perkova, and E.V. Kholodova is devoted to the analysis of the historical and cultural environment of the Central Chernozem region and the protection of the cultural heritage of Belgorod Region. The paper discusses the options for adapting the object of cultural heritage, taking into account the investment attractiveness. The decision options are justified by a comprehensive assessment for decision-making.

The object of the study is the object of cultural heritage "Kurchaninov's Estate".

The aim of the study is to identify the optimal options for reconstruction with adaptation to the modern use of the object of cultural heritage, taking into account the investment attractiveness.

\section{Materials and methods}

To achieve this goal, we used integrated and environmental approaches, as well as retrospective analysis; comprehensive assessment of the territory; cartographic and landscape-visual analysis. The study uses archival sources and cartographic materials, as well as existing regulatory and advisory documents in the field of protection of the cultural heritage of the Russian Federation. The authors also propose to use an important stage of design - a comprehensive assessment of options according to criteria, based on the technology of integrated environmental assessment "Green Print" [8].This is a quantitative method for evaluating conceptual and design decisions based on criteria. In this study, a comprehensive assessment of the criteria was used to evaluate the developed options for reconstruction with adaptation to the modern use of the cultural heritage object. The list of criteria and questions for quantitative assessment were clarified in relation to the process of reconstruction of the cultural heritage site. As a result of the quantitative analysis, an objective result was obtained that allows evaluating the effectiveness of the developed proposals from the point of view of the population, authorities, business and other participants in urban development.

\section{Results and discussion}

Today the historical centers of municipal districts are often points of innovative growth and the development of cultural and historical traditions [5].

In the administrative centers of the municipal districts of Belgorod region, there are objects of cultural heritage that can be considered from the standpoint of their " ... correlations with the concept of "cultural values" [1]. Such value imperatives "... influence the decision to adapt an architectural monument for modern use (utilitarian-functional, urban planning, historical and emotional values)" [2].

We consider the objects of cultural heritage of regional significance - the buildings of the chancery and the city estate of Justice of the Peace Kurchaninov in Belgorod. The buildings of the chancery and the city estate of the Justice of the Peace Kurchaninov in Belgorod were an example of provincial classicism. The history of the ensemble began with the location in its place of the wooden house of the family of Vasily Drenyakin-a relative of Lieutenant General A.M. Drenyakin. Later, on the site of a wooden house, his son Dmitry built a house for his family in the middle of the $19^{\text {th }}$ century. A.P. Kurchaninov is a nobleman and a Justice of the Peace-became the owner of the house only on May 10, 1905. The estate consisted of two buildings: a residential building and an office, it was located on the corner of Razin Street (former Nikolskaya Street) and Pushkin Street (former 
Batalonnaya Street) near the Uspensko-Nikolaevsky and Pokrovsky parish churches. The location of the Kurchaninov estate in the Pushkin Street development played an important role, as the residential building closed the compositional axis of the street from the south side and "held" the corner of the building at the intersection of Razin and Pushkin Streets. That is why in the architectural composition of the main facade there is a grandeur and austerity at the same time.

Building No. 17 is a Slobodskoy individual one-story residential house of the manor type of the second half of the XIX century. Rectangular in plan, wooden, with the original stone south wall and partially stone partitions with adjacent heating stoves, on a high stone basement. In the basement in the southern half of the house there were living quarters, the rest was used as a utility basement. The plan of the first floor was enfilade-hall with a longitudinal central corridor. In the architectural composition of the main facade, the accentuating element is a four-column Doric portico, each column of which is placed on a separate high base. The portico is completed with a wooden entablature and a triangular pediment with a large rectangular window in the center.

Building No. 17A was built in the second half of the $19^{\text {th }}$ century to the south of the Kurchaninov residential building. It is a service building of the office of the Justice of the Peace Kurchaninov. The building is "L"-shaped in plan, two-storeyed in the main volume, the side wing is one-storeyed. The first floor is made of stone, the second is made of wood. The main facade is divided into three window axes. The windows are framed by stucco drawn architraves. The walls are plastered and whitewashed, the floors are separated by two shelves, the corners of the first floor and the inner wall are fixed with shovels. The corners and the inner wall on the second floor are decorated with pilasters, decorated with small niches along the entire height. The walls of the facades are completed with a profiled frieze and a wooden cornice. The roof is four-pitched. Heating stoves and stucco decoration were preserved in the interiors. Today, both buildings are objects of cultural heritage of regional significance and are in a critical condition.

As a result of the socio-functional adaptation of architectural monuments of regional significance for modern use, not only their historical value should be preserved, but also a harmonious spatial environment should be organized in the territories adjacent to them [1, 2]. Green spaces should be included as important elements of urban planning [14]. The principle of the genetic urban planning code is also taken into account, which should be implemented in spatial, architectural, and stylistic morphological parameters [3]. It is necessary to integrate the planning, development and sustainability of the ecosystem into a single process [11], as well as to create comfortable functional spaces and an aesthetic environment [12]. To improve the quality of life of citizens, the development of pedestrian infrastructure is also of great importance [13].

In this study, we propose a variant of reconstruction with the adaptation of the object for the creativity center. The center is intended for the education of the population, the development of the creative potential of young people, leisure of older groups of the population, introduction to the art of citizens and guests of the city. The general layout of the creativity center is a complex of three blocks, two of which are objects of reconstruction and one-the main one-the object of new capital construction. Block A consists of a library, a media library, reading rooms and a lecture hall and provides permanent free access for residents and visitors of the city. Block B consists of art and pottery workshops, spaces for co-working and business meetings with rented premises. Block $\mathrm{C}$ includes an exhibition space, lecture halls, dance studios, a recording studio, a photo studio, a theatre studio, and a rented meeting room. The adaptation of communication spaces for the implementation of modern educational forms [10] will allow realizing the various needs of the population. Block $\mathrm{C}$ provides for the placement of administrative offices, cafes on the first floor and small recreation areas (Fig. 1). 


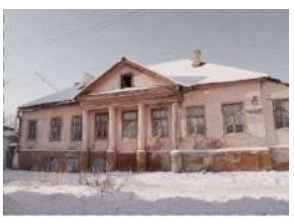

Current state

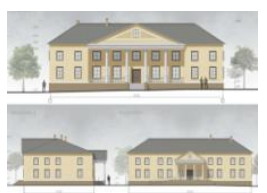

Design solution for facade restoration

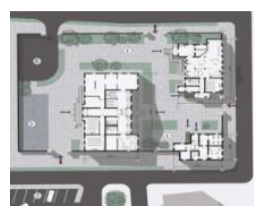

Projected general plan of the territory

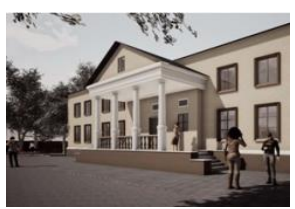

Rendering

Fig. 1. Fragments of the project proposal for reconstruction with the CHO adaptation "Kurchaninov's Estate". Developed by A.M. Dubino, I.N. Chechel.

To identify the effectiveness of the adopted design decisions, as well as to determine the main vector of development of the territory, it is proposed to use a comprehensive score assessment of reconstruction projects with the cultural heritage objects adaptation, which was clarified on the basis of [8].

The assessment is carried out on a 3-point scale (from 0 to 3). For each of the criteria, there are a number of questions that reveal the essence of each of the design decisions (Table 1).

Table 1. Comprehensive point assessment based on criteria.

\begin{tabular}{|c|c|c|c|}
\hline № & $\begin{array}{l}\text { Assessment } \\
\text { criteria }\end{array}$ & Questions on criteria & Points \\
\hline \multirow[t]{5}{*}{1} & \multirow[t]{5}{*}{ Resources } & $\begin{array}{l}\text { 1. Is the surrounding area included in the overall } \\
\text { concept? }\end{array}$ & 3 \\
\hline & & $\begin{array}{l}\text { 2. Are local construction and finishing materials } \\
\text { used for the reconstruction of adaptation facilities? }\end{array}$ & 2 \\
\hline & & $\begin{array}{l}\text { 3. Does it involve the use of secondary raw } \\
\text { materials? }\end{array}$ & 0 \\
\hline & & 4. Are nearby abandoned areas being used? & 2 \\
\hline & & Total by criterion & 7 \\
\hline \multirow[t]{6}{*}{2} & \multirow[t]{6}{*}{ Transport } & $\begin{array}{l}\text { 1. Is there a public transport stop no more than } 500 \\
\mathrm{~m} \text { from the design site? }\end{array}$ & 3 \\
\hline & & $\begin{array}{l}\text { 2. Is the object provided with a convenient entrance } \\
\text { for owners of personal transport and the number of } \\
\text { parking spaces? }\end{array}$ & 3 \\
\hline & & $\begin{array}{l}\text { 3. Does it involve improving transport accessibility } \\
\text { by increasing the number of vehicles or changing } \\
\text { the schedule of public transport? }\end{array}$ & 1 \\
\hline & & $\begin{array}{l}\text { 4. Does the improvement of the pedestrian network } \\
\text { for access to the planned site involve? }\end{array}$ & 3 \\
\hline & & $\begin{array}{l}5 . \text { Does it ensure the safety of walking and cycling } \\
\text { routes? }\end{array}$ & 2 \\
\hline & & Total by criterion & 12 \\
\hline \multirow[t]{5}{*}{3} & \multirow[t]{5}{*}{ Location } & 1. Does the design solution support historical value? & \\
\hline & & $\begin{array}{l}\text { 2. Does it bring functional diversity to the design } \\
\text { area? }\end{array}$ & \\
\hline & & 3. Does the "place brand" apply? & \\
\hline & & $\begin{array}{l}\text { 4. Are the conditions created for the sustainable and } \\
\text { continuous development of the territory? }\end{array}$ & \\
\hline & & 5. Are there points of attraction for large groups of & \\
\hline
\end{tabular}




\begin{tabular}{|c|c|c|c|}
\hline & & the population, including visitors to the city? & \\
\hline & & Total by criterion & 12 \\
\hline 4 & Society & $\begin{array}{l}\text { Does it meet the different needs of all population } \\
\text { groups (recreation, leisure, education, etc.)? }\end{array}$ & 3 \\
\hline & & $\begin{array}{l}\text { Does it preserve the character of the local identity } \\
\text { and strengthen the local ties of society? }\end{array}$ & 2 \\
\hline & & $\begin{array}{l}\text { Does it create conditions for interaction between } \\
\text { different age groups? }\end{array}$ & 3 \\
\hline & & $\begin{array}{l}\text { Is there provision for social and socio-cultural } \\
\text { infrastructure services? }\end{array}$ & 3 \\
\hline & & Is it accessible to people with limited mobility? & 3 \\
\hline & & Total by criterion & 14 \\
\hline 5 & Business & $\begin{array}{l}\text { 1. Does it provide an opportunity to create new } \\
\text { business spaces? }\end{array}$ & 2 \\
\hline & & $\begin{array}{l}\text { 2. Does it support the existence of retail trade and } \\
\text { services? }\end{array}$ & 1 \\
\hline & & $\begin{array}{l}\text { 3. Does it create new jobs, including during the } \\
\text { construction phase? }\end{array}$ & 3 \\
\hline & & Total by criterion & 6 \\
\hline 6 & Buildings & $\begin{array}{l}\text { 1. Does the restoration (reconstruction) of the lost } \\
\text { parts/elements/ on the territory of the cultural } \\
\text { heritage object involve? }\end{array}$ & 3 \\
\hline & & $\begin{array}{l}\text { 2. Do new capital construction projects appear on } \\
\text { the territory adjacent to the CHO? }\end{array}$ & 3 \\
\hline & & $\begin{array}{l}\text { 3. Does it make effective use of the space-planning } \\
\text { and structural potential of adaptable objects } \\
\text { (buildings) under the new function? }\end{array}$ & 3 \\
\hline & & Total by criterion & 9/9 \\
\hline 7 & $\begin{array}{l}\text { Reviving the } \\
\text { historical }\end{array}$ & $\begin{array}{l}\text { 1. Is there the restoration of a complete historical } \\
\text { environment? }\end{array}$ & 3 \\
\hline & heritage & $\begin{array}{l}\text { 2. Does the design solution help to identify the } \\
\text { identity of the local architectural environment? }\end{array}$ & 2 \\
\hline & & $\begin{array}{l}\text { 3. Is the subject of protection taken into account in } \\
\text { all stages of design? }\end{array}$ & 3 \\
\hline & & $\begin{array}{l}\text { 4. Does the design solution fully or partially reflect } \\
\text { the original functions of the building? }\end{array}$ & 0 \\
\hline & & $\begin{array}{l}\text { 5. Does the restoration of the original space- } \\
\text { planning structure, exterior and interior of the } \mathrm{CHO} \\
\text { provide? }\end{array}$ & 3 \\
\hline & & Total by criterion & 11 \\
\hline 8 & Ecology & $\begin{array}{l}\text { 1. Does the existing natural framework still exist in } \\
\text { the area adjacent to the CHO? }\end{array}$ & \\
\hline & & $\begin{array}{l}\text { 2. Is there sufficient species diversity in landscaping } \\
\text { to ensure the ecological balance of the surrounding } \\
\text { area? }\end{array}$ & \\
\hline & & $\begin{array}{l}\text { 3. Is there sufficient provision for greening the } \\
\text { territory of the adaptation object? }\end{array}$ & \\
\hline & & $\begin{array}{l}\text { 4. Does it involve the use of alternative energy } \\
\text { sources? }\end{array}$ & \\
\hline
\end{tabular}




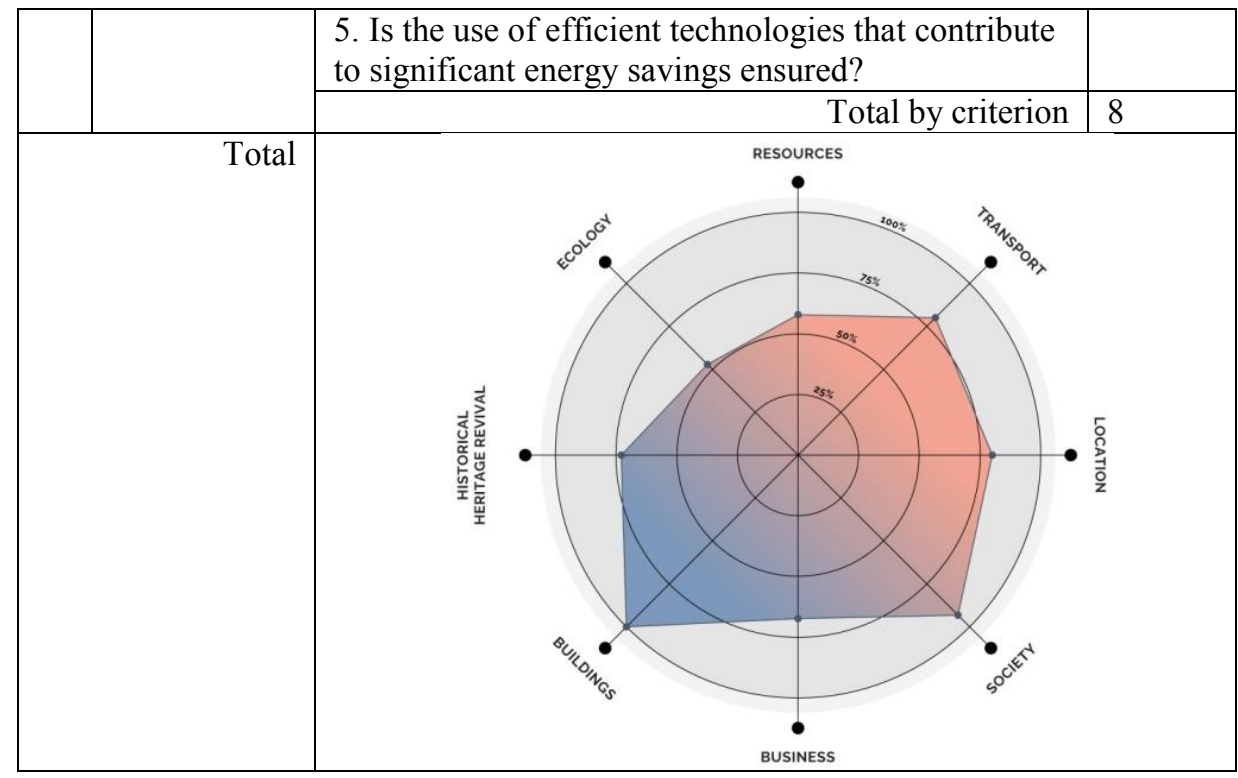

\section{Conclusion}

The resource potential of the cultural heritage object was studied. Two variants of reconstruction with adaptation to new functions, taking into account the investment attractiveness of the object, are proposed.

The technology of integrated environmental assessment "Green Print"is adapted by the authors for a comprehensive assessment of the effectiveness of cultural heritage objects adaptation for modern use. The criteria and questions for quantitative assessment were clarified.

A comprehensive assessment of the effectiveness of the developed project proposals according to the criteria of the cultural heritage object was carried out. The optimal conceptual design proposal is identified, taking into account the investment attractiveness of the object.

Thus, the measures proposed in the study will help to preserve the object of cultural heritage, create new jobs, and implement cultural and social projects for various consumer groups.

The work was carried out as part of the implementation of the Development Program of the reference university on the basis of BSTU named after V.G. Shukhov until 2021. Contract No. A-53/20. Research topic: Urban development of industrial territories of urban settlements

\section{References}

1. S.V. Bulavsky, S.V. Sementsov, Approaches to the definition of the category "object of cultural heritage" in the Russian legal field Protection and restoration of cultural heritage monuments, Materials of the All-Russian Scientific and Theoretical Conference. ed. by S.V. Sementsov 12-16 (2018).

2. E.V. Sergeeva, S.V. Sementsov, Basic principles of legal regulation of the adaptation of cultural heritage objects for modern use in Russian legislation Protection and restoration of cultural heritage monuments, Materials of the All-Russian Scientific and 
Theoretical Conference. ed. by S.V. Sementsov 138-140 (2018).

3. S.V. Sementsov, Bulletin of the St. Petersburg University. Art History 2, 190-211 (2013).

4. M.V. Perkova, Urban development of the regional settlement system and its elements (on the example of Belgorod region), PhD Thesis (Moscow, 2019).

5. M. Perkova, A. Zaikina, Architecture and Engineering 1(3), 18-23 (2016).

6. M.V. Perkova, E.V. Baklazhenko, A.G.A. Vaytens, IOP Conference Series: Earth and Environmental Science 459(5), 052024 (2020).

7. M.V. Perkova, O.E. Roshupkina, L.I. Kolesnikova, A.G. Vaytens, IOP Conference Series: Materials Science and Engineering 698(3), 033006 (2019).

8. D. Plater "Hertfordshire. Guide to Growth-2021. How Should the County Grow?" by Duany Plater-Zyberk \& Company (http://www.dpz.com) Published by University of Hertfordshire Press Learning and Information Services University of Hertfordshire College in Great Britain (2009).

9. J. Kenworthy, Environment and Urbanization 18(1), 67-85 (2006).

10. S.V. Ilvitskaya, M.V. Perkova, L.V. Petrova, O.A. Shulginova, IOP Conference Series: Materials Science and Engineering 698(3), 033024 (2019).

11. B. Milojevic, 2015Integrated urban planning in theory and practiceModern theory and practice in construction 13(1), 323-337 (2015).

12. S. Çelikyay, A Theoretical Framework on Retro-Fitting Process Based on Urban Ecology Sustainable Urbanization InTech (2016).

13. L.E. Jackson, Landscape and Urban Planning 64(4), 191-200 (2003).

14. J.R. Wolch, J. Byrne, J.P. Newell, Landscape and Urban Planning 125, 234-244. 2014doi:10.1016/j.landurbplan.2014.01.017

15. M. Perkova, Y. Tsvetkova, Architecture and Modern Information Technologies 4(53), 135-151 (2020). 